\title{
THE IMPACT OF SOCIAL MEDIA ON TOURISM
}

\author{
Radmila Živković, Jelena Gajić, Ivana Brdar \\ Singidunum University, Belgrade, Serbia
}

\begin{abstract}
:
The tourism system mainly relies on information and communication technologies for promotional activities, sales and when developing management relationships with customers. When a tourist is making the final decision on destination choice, the most important information comes from online interpersonal influence - online word of mouth (eWOM). Authors dealing with tourism market segmentation recognize the growing number of tourists who use modern digital media. In accordance with their identified needs, advanced technologies provide a new customized tourist offer. Contemporary tourists have been more than active since the emergence of the sophisticated Web 2.0 technology which strongly influenced and transformed the travel decision making process. Many surveys results confirm that - approximately $50 \%$ of people are likely to download travel applications while searching for destinations before they actually leave for vacation.
\end{abstract}

\section{Key words:}

social media,

tourism,

Web 2.0,

tourists,

eWOM.

\section{INTRODUCTION}

The revolutionized meaning of information communication technologies and Internet technologies refers to mobile communications which enable individuals to move and generate, transmit and receive different kinds of information. As a result of this process, various models of communication emerged. With the help of information communication technology in the global environment, individuals may interact, move through space and time and their necessary information accompany and help them to find the desirable product or services [1].

The aim of this article is to present how and to what extent information and communication technologies have affected tourism. We shall consider the tourism system and its participants (stakeholders and tourists) the essential area of study in attempt to explain this phenomenon. Analyzing the network consisted of different digital components can offer a different view for understanding dynamic behavior of our digital users who can be converted into tourists with assistance of social media.

\section{CONTEMPORARY COMMUNICATIONS IN TOURISM}

Companies in tourism try to combine varied marketing techniques they used in the past and they analyze several specific factors in the process of developing communication mix strategy (type of tourism market, traveler's readiness to make purchase, destination development stage, and the brand's market share and positioning). Sophisticated target groups and modern ICT environment great importance to send the right messages through the proper media channels [2].

From "the static web" and unidirectional flow of communication until "the second phase" of Web 2.0 and bidirectional communication, new levels of relations have started up. The user may create, share, collaborate and communicate. Therefore, Web 2.0 has an enormous impact upon tourists' behavior. According to the new information technology trends, consumers started being more adaptive and flexible, and a new consumer profile emerged - the digital users [3]. The new type of consumers leads to new experiences. With new technologies being developed, the main interest of tourism subsequently lies in exploring the potential of ICTs, and particularly social networking, as strategic instruments for positive enhancement of tourism experiences [4].

As a result of the Web 2.0 concept extension in the tourism sector, there is another innovation called Travel 2.0 which represents the new generation of travel websites. Its new technologies facilitate social collaboration among travellers enabling tourists to share their experiences with fellow travellers [5]. The credibility and trustworthiness of Travel 2.0 applications are increasing and today`s tourists trust these travel applications more than professional travel advice.

The effective marketing communications do not lie in what you say, but how you say it, considering the marketing channels and creativity of the message. The traditional approaches to communication put emphasis on mass media techniques which are less effective in the environment where tourists have access to large amounts of information on destinations, arrangements, hotels, etc. Also, social networks have the most effective influence on 
tourism when they rely on the effects of the Web 2.0 while trying to deal with new tourists' expectations. In support of such arguments: (a) The European Travel Monitor suggests that six out of ten Europeans who went on a holiday trip during 2012 used the internet; (b) TripAdvisor, which receives more than 60 million unique visitors each month (TripAdvisor, 2012)and more than 125 million reviews and opinions on more than 3.1 million accommodation facilities, restaurants and attractions (TripAdvisor, 2013) and (c) eMarketer (2013) found that around 163.5 million people in the US-more than two-thirds of internet users-are social network users [6].

There are many communication options where consumers can search, interact and share information with other users. There, in the table below, we can see some of the interactive marketing communication options that are now available.

Table 1. Digital Marketing Communication Options

\begin{tabular}{|c|c|}
\hline & Digital Marketing Communication Options \\
\hline Website & $\begin{array}{l}\text { Companies must design web sites that em- } \\
\text { body or express their purpose, history, prod- } \\
\text { ucts and vision. The key challenge is to design } \\
\text { a site that is attractive at first sight and in- } \\
\text { teresting enough to encourage repeat visits. } \\
\text { Dedicated websites for mobile devices are on } \\
\text { the increase. }\end{array}$ \\
\hline $\begin{array}{l}\text { Social } \\
\text { Media }\end{array}$ & $\begin{array}{l}\text { Companies are embracing social media be- } \\
\text { cause of its potential for engagement and } \\
\text { collaboration with consumers. Social media } \\
\text { advertising will yield relatively stronger re- } \\
\text { sults because of its ability to tightly target } \\
\text { audience based on social media activity. }\end{array}$ \\
\hline $\begin{array}{c}\text { Mobile } \\
\text { Marketing }\end{array}$ & $\begin{array}{l}\text { Mobile phone marketing will become in- } \\
\text { creasingly important. Smart phone use in } \\
\text { particular is growing amongst travelers. }\end{array}$ \\
\hline $\begin{array}{l}\text { Internet- } \\
\text { Specific } \\
\text { Ads and } \\
\text { Videos }\end{array}$ & $\begin{array}{l}\text { With user-generated content sites such as } \\
\text { You Tube. My Space Video and Google Video, } \\
\text { consumers and advertisers can upload ads } \\
\text { and videos to be shared virally by millions of } \\
\text { people. }\end{array}$ \\
\hline $\begin{array}{c}\text { Display } \\
\text { Ads }\end{array}$ & $\begin{array}{l}\text { Display ads are small, rectangular boxes con- } \\
\text { taining text and perhaps a picture that com- } \\
\text { panies pay to place on relevant web sites. } \\
\text { The larger the audience, the more the place- } \\
\text { ment costs. }\end{array}$ \\
\hline Microsites & $\begin{array}{l}\text { A microsite is a limited area on the Web man- } \\
\text { aged and paid for by an external advertiser/ } \\
\text { company. Microsites are individual Web pag- } \\
\text { es or cluster of pages that function as supple- } \\
\text { ments to a primary site. }\end{array}$ \\
\hline Search Ads & $\begin{array}{l}\text { Paid-search or pay-per-click ads represent } \\
40 \% \text { of all on-line ads. Thirty-five percent of } \\
\text { all searches are reportedly for products or } \\
\text { services. These arch terms serve as a proxy } \\
\text { for the consumer's consumption interests } \\
\text { and trigger relevant links to product or ser- } \\
\text { vice offerings alongside search results from } \\
\text { Google, MSN and Yahoo! Advertisers pay } \\
\text { only if people click on the links. }\end{array}$ \\
\hline
\end{tabular}

\begin{tabular}{|c|l|}
\hline $\begin{array}{c}\text { Online } \\
\text { Communi- } \\
\text { ties }\end{array}$ & $\begin{array}{l}\text { Digital Marketing Communication Options } \\
\text { ties whose members communicate through } \\
\text { postings, instant messaging and chat discus- } \\
\text { sions about special interests related to the } \\
\text { company's products and brands. }\end{array}$ \\
\hline \multirow{5}{*}{ Interstitials } & $\begin{array}{l}\text { Interstitials are advertisements, often } \\
\text { with video or animation, that pop up be- } \\
\text { tween changes on a website, e.g., ads for } \\
\text { Johnson\&Johnson's Tylenol headache re- } \\
\text { liever would pop up on brokers' websites } \\
\text { whenever the stock market fell by 100 points } \\
\text { or more. }\end{array}$ \\
\hline Blogs & $\begin{array}{l}\text { Blogs are usually maintained by an individual } \\
\text { with regular entries of commentary, descrip- } \\
\text { tions of events, or other material such as } \\
\text { graphics or video. Most good quality blogs } \\
\text { are interactive, allowing visitors to leave } \\
\text { comments and even messages each other. }\end{array}$ \\
\hline \multirow{5}{*}{ E-mail } & $\begin{array}{l}\text { Email uses only a fraction of the cost of a 'd- } \\
\text { mail', or direct mail campaign. }\end{array}$ \\
\hline
\end{tabular}

Source: Hudson, S., Roth, M., Madden, J.T., (2012), Customer Communications Management in the New Digital Era, Center for Marketing Studies, Darla Moore School of Business, University of South Carolina, p.6.

As more aspects of everyday life converge toward digital, opportunities for tourist's organizations to interact with tourists expand dramatically [7]. According to professional opinion, social media are more reliable and their content is wide and varied.

\section{SOCIAL MEDIA AS AN IMPORTANT TOOL FOR TOURISM}

Social media is an important tool for the analysis of tourists' attitudes and this is confirmed by the increased purchases and recommendations to other users. Building successful service-based brand in tourism means that each offer should be a unique value proposition based on the customer experience.

Tourists need to know by means of reliable sources how their experience is going to be like in order to reduce uncertainty and create some expectations of what they are going to find at a destination [8].

Due to the uncertainty of tourist services, a traveller should obtain the necessary information in order to make the right decision concerning the travel. Modern tourists have more trust in other travellers' opinions using social media rather than official marketing advices.

As social media becomes increasingly expressive, consumers are able to increasingly influence other consumers with their own opinions and experiences. Since social media is low-cost and bias-free, it represents an advantage for marketing communications [9]. According to the Fotis and in the academic literature there is a disagreement on the classification of the social media types according to their level of social presence/media richness and the 
level of self-presentation/self-disclosure. Six types of social media have been identified: social networking websites (i.e. Facebook, Linkedin), blogs, content communities (i.e.YouTube, Flickr, Scrib, Slideshare, Delicious), collaborative projects (i.e. Wikipedia, Wikitravel), virtual social worlds (i.e.Second Life), and virtual game worlds (i.e. World of Warcraft). However, there are other types of social media such as microblogs (i.e. Twitter), consumer review \& rating websites (i.e. TripAdvisor, Epinions) and internet fora (i.e. ThornTree, Fodor's Travel Talk) [10].

Evidently, the number of social media is changeable, but their most important role is to encourage users and travellers to post and share their travel experiences, comments and opinions, by having them serve as a source of information for other users.

Social media continues to impact communication either positively or negatively depending on the subjects under study and the type of communication (Steven M. Edwards) [11]. Social media requires all marketing activities integration and uses persuasive advertising to provide a competitive product/service experience.

The electronic word of mouth is important for marketers to understand this new platform for communication and support customer relationship in the best way. The electronic Word of Mouth can enhance visitor satisfaction due to product or service improvement. At the same time, eWOM can solve problems and doubts during the travel and it can help discover what tourists think and say about their experience. However, the main benefit can be monitoring of the company's reputation/image or even the analyses of the current competitive strategies [12].

According to the eMarketer, (Fig.1) by the end of 2015, 174,9 million people in the USA will be social network users.

Fig.1. US Social Network Users and Penetration, 2012-2017

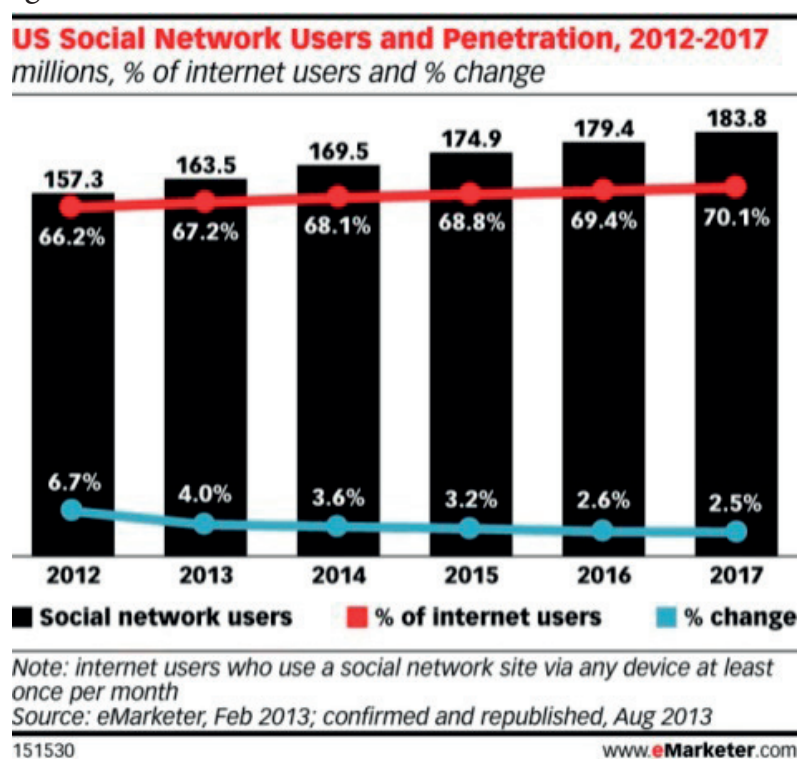

Source: http://www.emarketer.com/

Facebook in particular has a great influence over consumer choices globally, especially in the travel sector. The research conducted in 2012 has shown that $76 \%$ of travellers post vacation photos on a social network and $40 \%$ from all over the world say they trust recommendations from friends, such as word-of-mouth, and only $48 \%$ of all the travelers who used social media to create travel plans, stuck with their original travel plans [13].

Digital technologies have contributed to fundamental changes in the tourism industry and determined a better understanding of the decision making process of the travel, tourists' behavior during vacation and post vacation activities.

An online research with 4,600 respondents was conducted in October, 2012 across the US, Europe (EMEA) and Asia Pacific (APAC), specifically with Internet and social media users among travellers (who had traveled for leisure purpose in the last 12 months or intended to do so in the next 12 months) [14].

This interesting study collected the most important information related to the impact of social media on tourism. The study revealed that social media has a big influence on travel decisions as $44 \%$ of respondents strongly agreed that Internet reviews posted by travel bloggers helped them about the initial decision of vacation destinations. This is followed by $37 \%$ online travel forums, $27 \%$ Facebook, 24\% Youtube/Vimeo, 22\% Pinterest.

Nearly half of the respondents would have used social media to plan their vacation if free $\mathrm{Wi}-\mathrm{Fi}$ had been available.

From those who are "social active", over 50\% are likely to download travel apps while planning their vacation before they go. During vacation, the most popular application is (by 15\%) Google Maps (Figure 2). After that come city guides, local weather, restaurant finder apps and public transportation apps.

Fig.2. The most popular applications during vacation

\section{Apps Used During Vacation}

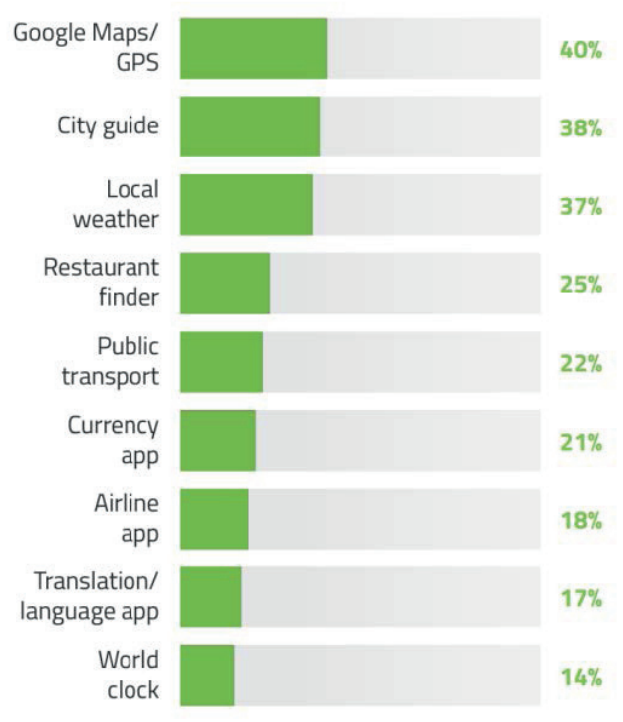

Source: Text100 Digital Index: Travel \& Tourism study 2012, retrieved from www.text100.com

The survey's results (Figure 3 ) regarding top 5 things travellers are most likely to comment online have indicated that travellers enjoy commenting on shopping, local 
cuisine, fine food, historical sites, museums and galleries, as well as amusement/theme parks.

Fig.3. Top five things travalers are most likely to comment on Online

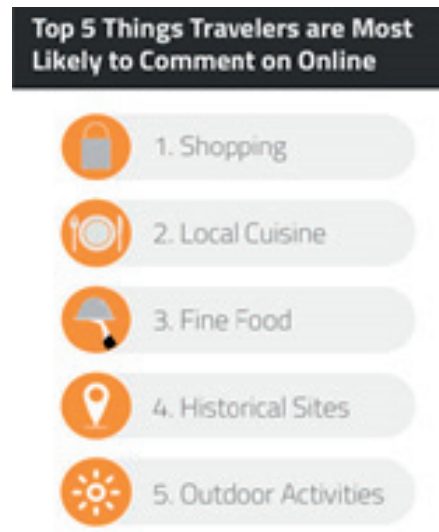

Source: Text100 Digital Index: Travel \& Tourism study 2012, retrieved from www.text100.com

Digital users in tourism can interact and share information with other tourists/friends using different platforms (blogs, forums, wikis, video and photo sharing to social networks, virtual communities, chat rooms and pod-cast). The most popular activity during and post vacation among tourists is sharing self made videos or photos. After vacation almost $25 \%$ are proactive travellers as they writing reviews versus $20 \%$ of them who do it during vacation.

Travellers from Asia Pacific are more likely to share blogs posts or news stories related to their travel destination, while on vacation (Figure 4).

Fig.4. Social media activity during vacation Social Media Activity

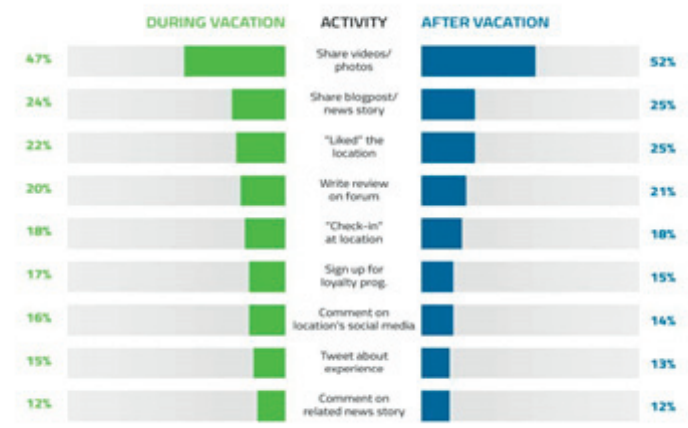

Source: Text100 Digital Index: Travel \& Tourism study 2012, retrieved from www.text100.com

The growth in travel related applications is likely to continue and tourism industry has to understand the motivating factors and travellers' needs in order to make connecting communities based on mutual interests.

\section{Conclusion}

Digital mobility and social media activities enable tourism industry to have appropriate insight in the world of tourists. Marketing communications will be mostly concentrated on the improvement of relationships in social media and adapting to tourists' needs. Social media has been recognized as one of important competitive tools in terms of tourism marketing. Tourism need to engage their tourists with multichannel integrated communications and encourage them to talk about and recommend good experiences. Engaging with travellers on real-time social media has huge implications for the travel industry.

Today tourists encounter with the new digital technology that can help them improve services and make their online experiences more personalized and more relevant - the Web 3.0. Beside many advantages of the next generation technology, probably, the big challenge for advanced ICT in the future will be facing with privacy and information reliability.

\section{REFERENCES}

[1] Poster, M., "Digitally Local, communications technologies and space", published by Die Deutsche Bibliothek, Communications in the 21st Century Edited by KristófNyíri, 2004., p.32

[2] Edelman, D., "Branding in the digital age", Harvard Business Review, 88(12), 2010., p. 62-69.

[3] Buhalis, D., Jun, H.S., "E-Tourism, Contemporary Tourism Reviews", Goodfellow Publishers Limited, Oxford, 2011., p.7

[4] Neuhofer,B.,Buhalis,D.,Ladkin,A.,, “A Typology of Technology-Enhanced Tourism Experiences", International Journal of Tourism Research, Int.J.Toruism Res., Published online in Wiley Online Library (wileyonlinelibrary.com) DOI: 10.1002/jtr.1958, 2013.

[5] Del Chiappa, G., "Trustworthiness of Travel 2.0 applictions and their influence on tourist behavior: an empirical investigation in Italy,In Law", R., Fuchs, M.\&Rucci, F.(Eds.), "Information and Communication Technologies in Tourism", New York, N.Y: Springer, 2011., p.331-342

[6] Fotis, J., Buhalis, D., Rossides, N., "Social Media Impact on Holiday Travel Planning: The Case of the Russian and the FSU Markets", International Journal of Online Marketing, 1(4), 1-19, October-December 2011, p.2.

[7] Mulhern, F. (2009). Integrated marketing communications: from media channels to digital connectivity. Journal of Marketing Communications, 15(2-3), 85-101.

[8] Zeithaml, V.A., Bitner, M.J. and Gremler, D.D., "Services marketing: Integrating customer focus across the firm", 4th ed. London: McGraw-Hill, 2006.

[9] Kotler,P., Kartajaya,H., Setiawan,I., “Marketing 3.0.”, John Wiley\&Sons,inc, New Jersey, , 2010, p.8,9.

[10] Fotis, J., Buhalis, D., Rossides N., "Social media use and impact during the holiday travel planning process", Information and Communication Technologies in Tourism, 2012, pp. 13-24.

[11] Edwards, S., "A Social Media Mindset, Temerlin Advertising Institute at Southern Methodist University", Vol 12 No 1 Fall 2011, Available from http://www.jiad.org/article148. $\underline{\mathrm{html}}$, accesed 15.03.2014.)

[13] Litvin,W,S., Goldsmith,E,R., Pan, B., "Electronic word of mouth in hospitality and tourism management", Tourism Management, Vol. 29, Issue 3, june 2008., pp. 458-468

[13] Hudson, S., Roth, S. M., Madden, J.T., "Customer Communications Management in the New Digital Era”, Center for Marketing Studies, Darla Moore School of business, University of South Carolina ,January 2012.. p.21

[14] Text100 Digital Index: Travel \& Tourism study 2012, retrieved from www.text100.com 